\title{
CCR2 Gene
}

National Cancer Institute

\section{Source}

National Cancer Institute. CCR2 Gene. NCI Thesaurus. Code C101577.

This gene plays a role in chemokine signaling. 